\title{
THE SUSCEPTIBILITY OF CERTAIN CANTALOUPE CULTIVARS TO DIFFERENT THREE PESTS INFESTAION IN QUALYOBIA GOVERNORATE, EGYPT
}

\author{
METWALLY, SAMIA A.G. ${ }^{1}$, I. F. SHOUKRY ${ }^{2}$, M.W.F. YOUNES ${ }^{3}$ and \\ YOMNA N. M. ABD-ALLAH ${ }^{1}$
}

\author{
1 Plant protection Research Institute, ARC, Dokki, Giza, Egypt \\ 2 Zoology Department, Faculty of Science, Zagazig University, Egypt \\ 3 Zool. Dept. Fac. of Sci. Menoufia Univ., Egypt
}

(Manuscript received 10 April 2012)

\begin{abstract}
Field and laboratory studies were carried out during two successive summer seasons in order to study the susceptibility of the different tested cantaloupe cultivars namely (Ideal, E81-065, Mirella ,Vicar, E81-013 and Magenta) to infestation by Thrips tabaci, Bemisia tabaci and Tetranychus urticae. Field studies were carried out during the two consecutive growing seasons (2006 and 2007). There were significant differences in the susceptibility of cantaloupe cultivars to infestation by these pests. These mentioned that, E81-065 and Magenta cultivars were the lowest infested ones by these pests. On the other hand, Mirella variety was the highest infested cultivar. To give a spot light on the reason of the differences in the susceptibility of the tested cantaloupe cultivars, chemical analysis of the dried leaves were carried out during growing season of 2007. Chemical analysis of infested leaves showed correlation between certain phytochemical components (organic and inorganic compounds); reduced, non-reduced and total sugars, potassium, total protein, carbohydrate, and phosphorous as well as moisture content and population density of T. tabaci, B. tabaci and T. urticae.
\end{abstract}

\section{INTRODUCTION}

Cantaloupe, Cucumis melo L. (Family : Cucurbitaceae) considered as one of the most important and promising cucurbitaceous vegetable crop planted in Egypt and other world countries in the open field as well as under greenhouse conditions. In recent years new high yielding varieties and cultivars were introduced to accommodate the local consumption and increase harvesting area especially in the new reclaimed land. Watt and Merrill (1963), stated that, each $100 \mathrm{gm}$ of cantaloupe contains chiefly considerable amounts of water, energy, protein, fats, carbohydrates, fiber, ash, calcium, phosphorous, iron, sodium, potassium. According to the report of the Economic Affairs Sector, Egyptian Ministry of Agriculture in 2008, the cultivated cantaloupe area reached about 16213 feddan in the three main plantation (summer, winter and nili ones) in all Egyptian Governorates. This cucurbit is liable to be infested 
by numerous pests throughout seedling, flowering and fruiting stages of plant age. According to study carried out for the population density of the pests attack cantaloupe cultivarsit was found that, the most destructive are the cotton and onion thrips; Thrips tabaci, the cotton and tomato whitefly; Bemisia tabaci and the two spotted spider mite; Tetranychus urticae. These mentioned that, the forcited pests proved to have serious damage in plant leaves by sucking cell sap which lead to great reduction in both quantity and quality yield, on the other hand by causing indirect damage by transferring virus diseases (Duffus, 1987). The currently unwise use of pesticides eventually destroy the natural enemies (Osman et al., 1985) besides environmental contamination and induce insect resistance. Therefore, it is necessary to apply alternative methods to control the insect pests. So, the current investigation was mostly built up to select the lowest infested cultivars with these pests as one of the control options to suppress heavy pests infestations in Integrated Pest Management (I.P.M.) programs and as a result the resistant and susceptible varieties reviewed in the present study is one of the important reasons which have to be add to inheritance as sources of resistance.

\section{MATERIALS AND METHODS}

\section{Field studies}

Field experiment was conducted for two successive growing seasons; 2006 and 2007 during summer plantation at the experimental farm of Plant Protection Research Institute Station at Qaha region, Qualyobia Governorate.

\section{1-Susceptibility of different cantaloupe cultivars to infestation rate} induced by certain sap- sucking pests .

Six cantaloupe cultivars namely ( Ideal, E81-065, Mirella, Vicar, E81-013 and Magenta ) were planted to study their susceptibility to infestation by T. tabaci, B. tabaci and T. urticae during summer plantation season of 2006 and 2007 . An area of about $2100 \mathrm{~m}^{2}$ was cultivated with the six tested cantaloupe cultivars during the studied seasons. Seeds were sown on April $13^{\text {th }}$ and $16^{\text {th }}$ for 2006 and 2007, respectively. The experimental area was divided into 18 equal plots (of about $116.67 \mathrm{~m}^{2}$ ) and each of the six tested cultivars was replicated three times in a complete randomized block design comprising 54 rows and 30. apart between hills. All the usual agricultural practices for cultivation of cantaloupe were applied and the whole experimental chemical control measures were entirely avoided during the plant season. 


\section{Sampling technique}

Sampling started weekly after about two weeks from cultivation. One hundred and eighty leaves ( 10 leaves $\times 3$ replicates $\times 6$ varieties) were randomly picked out from different levels " upper, middle and lower" of the plant in the morning .Plants were examined in the field, then randomized leaf samples were kept separately in polyethylene bags and then transferred to the laboratory.

The population of $B$. tabaci nymphs and $T$. urticae motile stages were estimated by counting numbers per two square inches. However, the total individuals (nymphs+ adults) of T. tabaci were determined by counting the total number per the whole underside leaf.

During the second season of study, 2007, leaf samples were collected from the different six tested cantaloupe varieties during seedling, flowering and fruiting stages to study the effect of certain organic and inorganic compounds in cantaloupe leaves on the infestation rate of T. tabaci, B. tabaci and T. urticae at their different developmental stages . Leaves of each samples were cleaned and washed with distilled water, then quickly dried by placing gently between filter papers to remove the excess of water. The fresh weight of leaves was determined. . The leaves were placed in a drying oven at $60^{\circ} \mathrm{C}$ for 24 hours. The dried leaves were crushed to fine powder, then the dry powder was stored in glass bottles to determine carbohydrates and protein contents according to the methods of Pregl (1945) and Michel et al. (1956). The percentages of reduced, non-reduced and total sugars were also estimated in the dry powder using the method of Forsee (1938). As well as, the phosphorous content was determined according to method of Troug and Meyer ( 1939). The analysis of leaf samples were conducted in Agricultural and Analysis Center, Faculty of Agriculture at Moshtohor, Benha University. Statistical analysis was conducted by using SAS program. ' $F$ ' test used to evaluate the differences significancy between treatments and mean separation was conducted using Duncan's multiple range test to arrange the tested cultivars in groups according to their susceptibility to certain studied pests in the above-mentioned program. The simple correlation was also obtained by using this program.

\section{RESULTS AND DISCUSSION}

\section{I-Field studies :}

\section{A. T. tabaci:}

It is clear from the obtained results in Tables (1\&2) that all of the tested cantaloupe cutivarswere infested by nymphs and adults of $T$. tabaci during the period of the present study (30 April till 7 August, 2006). 


\section{1-Infestation rate of T. tabaci during growing 2006 season:}

The mean number of $T$. tabaci nymphs and adults on all the tested cultivars revealed that, the highest infestation rate (peak) was recorded from third week of June till the second week of July 2006.

Statistical analysis indicated that, there was a highly significant difference between the tested cultivars. It is clear from the Duncan's multiple range test between means that, both of Mirella and E81-013 were the most susceptible varieties to T. tabaci; Vicar and E81-065 varieties were moderately infested and the lowest infested were Ideal and Magenta cultivars.

Table 1 . Weekly mean number of $T$. tabaci (nymphs \& adults) / leaf of the tested cantaloupe C. melo cultivars at Qaha region, Qualyobia Governorate during summer plantation season of 2006.

\begin{tabular}{|c|c|c|c|c|c|c|}
\hline \multirow{2}{*}{ Cultivars } & \multicolumn{5}{|c|}{ Mean number of T. tabaci individuals / leaf } \\
\cline { 2 - 7 } $\begin{array}{l}\text { Inspection } \\
\text { date }\end{array}$ & Ideal & $\begin{array}{c}\text { E81- } \\
065\end{array}$ & Mirella & Vicar & $\begin{array}{c}\text { E81- } \\
013\end{array}$ & Magenta \\
\hline $30 / 4 / 2006$ & 2.2 & 4.2 & 4.9 & 3.2 & 5 & 1.5 \\
\hline $7 / 5 / 2006$ & 5.8 & 7 & 8.9 & 5.8 & 6 & 4.8 \\
\hline $14 / 5 / 2006$ & 7.3 & 9.1 & 11.9 & 6.45 & 6.9 & 5.1 \\
\hline $21 / 5 / 2006$ & 7.7 & 8.9 & 10.8 & 8.1 & 7.2 & 4.8 \\
\hline $28 / 5 / 2006$ & 9.9 & 9.2 & 10.6 & 8.7 & 9 & 6.7 \\
\hline $4 / 6 / 2006$ & 10.1 & 11.1 & 12.4 & 9.3 & 11.4 & 8.9 \\
\hline $11 / 6 / 2006$ & 12.8 & 12.5 & 18 & 14.1 & 16.7 & 10 \\
\hline $18 / 6 / 2006$ & 13.1 & 14.3 & 17.7 & 16 & 27 & 12.6 \\
\hline $25 / 6 / 2006$ & 14.4 & 19 & 21.5 & 20.4 & 23 & 13.9 \\
\hline $2 / 7 / 2006$ & 16 & 17.6 & 22.3 & 21.5 & 22 & 13.4 \\
\hline $9 / 7 / 2006$ & 12.6 & 12.4 & 17 & 15.4 & 16.4 & 14.3 \\
\hline $16 / 7 / 2006$ & 10.4 & 15.2 & 19.5 & 15 & 18 & 13.1 \\
\hline $23 / 7 / 2006$ & 7 & 8.7 & 13 & 9.1 & 11.5 & 6.5 \\
\hline $31 / 7 / 2006$ & 5.6 & 8.5 & 15.2 & 8.2 & 11.4 & 5.3 \\
\hline $7 / 8 / 2006$ & 2.1 & 4.6 & 9.4 & 5.2 & 9.7 & 1.7 \\
\hline Mean & $9.13^{\mathrm{c}}$ & $10.82^{\mathrm{b}}$ & $14.20^{\mathrm{a}}$ & $11.1^{\mathrm{b}}$ & $13.41^{\mathrm{a}}$ & $8.17^{\mathrm{c}}$ \\
\hline \pm SE & \pm & \pm 1.13 & \pm 1.3 & \pm 1.45 & \pm 1.75 & \pm 1.15 \\
\hline F. value & 1.09 & & & & & \\
\hline L. S. D & \multicolumn{7}{|l|l|}{53.46} & & \\
\hline
\end{tabular}




\section{2-Infestation rate of $T$. tabaci during growing 2007 season:}

Data presented in Table (2) indicated that the infestation by the pest started at the last week of April, recording peaks during six weeks started at $11^{\text {th }}$ June till $2^{\text {nd }}$ July 2007 according to each cultivar.

It is clear from Duncan's multiple range test between means that both of E81013 and Mirella were the most susceptible cultivars. On the other hand, Vicar and Magenta were moderately infested. Ideal, E81-065 varieties considered as the less susceptible cultivars.

Table 2. Weekly mean number of $T$. tabaci (nymphs \& adults) / leaf of six cantaloupe C. melo cultivars at Qaha region, Qualyobia Governorate during summer plantation season of 2007.

\begin{tabular}{|c|c|c|c|c|c|c|}
\hline \multirow[b]{2}{*}{$\begin{array}{l}\text { Inspection } \\
\text { date }\end{array}$} & \multicolumn{6}{|c|}{ Mean number of $T$. tabaci individuals / leaf } \\
\hline & Ideal & $\begin{array}{l}\text { E81- } \\
065\end{array}$ & Mirella & Vicar & $\begin{array}{l}\text { E81- } \\
013\end{array}$ & Magenta \\
\hline $30 / 4 / 2007$ & 2 & 1.2 & 1.8 & 1.7 & 0.95 & 1.25 \\
\hline $7 / 5 / 2007$ & 4.2 & 3.8 & 3.7 & 6.1 & 3.95 & 6.3 \\
\hline $14 / 5 / 2007$ & 3.45 & 4.9 & 5.3 & 5.7 & 7.7 & 5.3 \\
\hline $21 / 5 / 2007$ & 3.25 & 3.56 & 4 & 4.6 & 8.5 & 6.6 \\
\hline $28 / 5 / 2007$ & 5.9 & 4.3 & 6.1 & 8.4 & 10.8 & 7.15 \\
\hline $4 / 6 / 2007$ & 1.32 & 3.85 & 8 & 5.6 & 5.6 & 5.45 \\
\hline $11 / 6 / 2007$ & 6.2 & 5.44 & 11.1 & 6.3 & 13.7 & 8.6 \\
\hline $18 / 6 / 2007$ & 5 & 7 & 9.2 & 6.3 & 8.7 & 4 \\
\hline $25 / 6 / 2007$ & 4.4 & 3.5 & 12.6 & 8.4 & 6.4 & 3.2 \\
\hline $2 / 7 / 2007$ & 6.5 & 2.5 & 8 & 6.7 & 9.6 & 2.9 \\
\hline $9 / 7 / 2007$ & 5.1 & 3.1 & 5.1 & 5.4 & 4.7 & 5 \\
\hline $16 / 7 / 2007$ & 2.6 & 2 & 3.6 & 3.6 & 4 & 3.1 \\
\hline $23 / 7 / 2007$ & 3 & 4.1 & 5 & 1.4 & 2.8 & 4 \\
\hline $31 / 7 / 2007$ & 1.2 & 0 & 1.7 & 0.8 & 3.1 & 2 \\
\hline $7 / 8 / 2007$ & 0.9 & 0 & 0 & 0 & 0.1 & 1.6 \\
\hline Mean & $3.67^{c}$ & $3.28^{c}$ & $5.68^{\mathrm{a}}$ & $4.73^{b}$ & $6.04^{\mathrm{a}}$ & $4.43^{b}$ \\
\hline$\pm \mathrm{SE}$ & \pm 0.48 & \pm 0.5 & \pm 0.92 & +0.69 & \pm 0.98 & \pm 0.56 \\
\hline F. value & \multicolumn{6}{|c|}{19.6} \\
\hline L. S. D & \multicolumn{6}{|c|}{0.68} \\
\hline
\end{tabular}




\section{B. B. tabaci}

\section{1-Infestation rate of $B$. tabaci nymphs during growing 2006season:}

Data tabulated in Table (3) show that The highest mean number of nymphs of B. tabaci nymphs recorded on $11^{\text {th }}$ of June. Accordingly Duncan's multiple range test between means considered that Vicar and Mirella represented the most susceptible varieties, on the contrary, Ideal, E81-013, Magenta and E81-065 were moderately infested cultivars.

Table 3. Weekly mean number of $B$. tabaci nymphs / in ${ }^{2}$ of six cantaloupe C.melo cultivars at Qaha region, Qualyobia Governorate during summer plantation season of 2006.

\begin{tabular}{|c|c|c|c|c|c|c|}
\hline \multirow[b]{2}{*}{$\begin{array}{l}\text { Inspection } \\
\text { date }\end{array}$} & \multicolumn{6}{|c|}{ Mean number of $B$. tabaci nymphs $/$ in $^{2}$} \\
\hline & Ideal & $\begin{array}{l}\text { E81- } \\
065\end{array}$ & Mirella & Vicar & $\begin{array}{l}\text { E81- } \\
013\end{array}$ & Magenta \\
\hline $30 / 4 / 2006$ & 2.1 & 0 & 3 & 0 & 0.1 & 0.8 \\
\hline $7 / 5 / 2006$ & 0.6 & 1.9 & 2.5 & 2 & 0.5 & 1.5 \\
\hline $14 / 5 / 2006$ & 3.5 & 0.6 & 6 & 2.5 & 1.7 & 0.6 \\
\hline $21 / 5 / 2006$ & 2.6 & 0.3 & 1.5 & 2.1 & 0.8 & 1.3 \\
\hline $28 / 5 / 2006$ & 0.6 & 0.5 & 2.6 & 2.4 & 0.7 & 2.9 \\
\hline $4 / 6 / 2006$ & 3.7 & 1.2 & 2.7 & 3.7 & 1.71 & 0.6 \\
\hline $11 / 6 / 2006$ & 1.6 & 2.1 & 1.3 & 4.2 & 2 & 1.4 \\
\hline $18 / 6 / 2006$ & 0.9 & 0.5 & 4.6 & 3.1 & 0.9 & 3.2 \\
\hline $25 / 6 / 2006$ & 1.6 & 2.8 & 8.1 & 6.3 & 2 & 2.9 \\
\hline $2 / 7 / 2006$ & 3.4 & 2 & 8.5 & 8 & 1.1 & 2.3 \\
\hline $9 / 7 / 2006$ & 3.9 & 3.2 & 5.1 & 4.6 & 4 & 3 \\
\hline $16 / 7 / 2006$ & 2.7 & 3.8 & 8.2 & 11.3 & 3.6 & 2.8 \\
\hline $23 / 7 / 2006$ & 3.8 & 2.7 & 6.7 & 10.4 & 5 & 4.4 \\
\hline $31 / 7 / 2006$ & 2.6 & 3 & 10.1 & 12 & 4.9 & 2.1 \\
\hline $7 / 8 / 2006$ & 3 & 3.5 & 3.8 & 8.7 & 6.5 & 0.9 \\
\hline Mean & $2.44^{b}$ & $1.87^{c}$ & $4.98^{\mathrm{a}}$ & $5.42^{\mathrm{a}}$ & $2.37^{b}$ & $2.05^{\mathrm{b}}$ \\
\hline$\pm \mathrm{SE}$ & \pm 0.3 & \pm 0.33 & \pm 0.73 & +0.98 & \pm 0.5 & \pm 0.29 \\
\hline F. value & \multicolumn{6}{|c|}{43.01} \\
\hline L. S. D & \multicolumn{6}{|c|}{0.67} \\
\hline
\end{tabular}




\section{2- Infestation rate of $B$. tabaci nymphs during growing 2007season:}

Results presented in Table (4) indicating that the highest average of population densities of $B$. tabacinymphs on the tested cultivars recorded during the first week of June and the first week of August. Accordingly Duncan's multiple range test between means of Vicar and Mirella indicated that these cultivars considered as the susceptible ones. On the other hand, the statistical analysis clearly indicated that Ideal and E81013 cultivars were moderately infested ones, while Magenta and E81-065 were the lowest infested.

Table 4. Weekly mean number of $B$. tabaci nymphs / $\mathrm{in}^{2}$ of six cantaloupe $C$. melo cultivars at Qaha region, Qualyobia Governorate during summer plantation season of 2007.

\begin{tabular}{|c|c|c|c|c|c|c|}
\hline \multirow{2}{*}{$\begin{array}{l}\text { Cultivars } \\
\text { Inspection } \\
\text { date }\end{array}$} & \multicolumn{6}{|c|}{ Mean number of $B$. tabaci nymphs $/$ in $^{2}$ per leaf } \\
\hline & Ideal & $\begin{array}{l}\text { E81- } \\
065\end{array}$ & Mirella & Vicar & $\begin{array}{c}\text { E81- } \\
013\end{array}$ & Magenta \\
\hline $30 / 4 / 2007$ & 2.9 & 2 & 0.6 & 3 & 0.9 & 2.4 \\
\hline $7 / 5 / 2007$ & 6.4 & 0.6 & 1.7 & 2.3 & 3.6 & 0.6 \\
\hline $14 / 5 / 2007$ & 5 & 3.8 & 2 & 5.5 & 2.3 & 3.5 \\
\hline $21 / 5 / 2007$ & 5.3 & 1.5 & 3.4 & 8.5 & 4.9 & 5.7 \\
\hline $28 / 5 / 2007$ & 7.1 & 0.9 & 4.2 & 2.2 & 8.2 & 3.2 \\
\hline $4 / 6 / 2007$ & 10.5 & 4.7 & 8 & 6.4 & 6.8 & 6.4 \\
\hline $11 / 6 / 2007$ & 8 & 4.6 & 6.6 & 4.9 & 11.5 & 4.8 \\
\hline $18 / 6 / 2007$ & 10.4 & 2.5 & 9.3 & 8.9 & 7.4 & 5.7 \\
\hline $25 / 6 / 2007$ & 11.2 & 6.6 & 4.2 & 12.5 & 7.4 & 5.4 \\
\hline $2 / 7 / 2007$ & 8.7 & 7.6 & 7.7 & 17.1 & 6.9 & 6.7 \\
\hline $9 / 7 / 2007$ & 3.8 & 3.1 & 7.5 & 10.8 & 7.1 & 2.5 \\
\hline $16 / 7 / 2007$ & 4.5 & 3.3 & 16.6 & 11.7 & 4.6 & 11.2 \\
\hline $23 / 7 / 2007$ & 5.4 & 2.8 & 6.7 & 7.4 & 5.5 & 5.7 \\
\hline $31 / 7 / 2007$ & 1.8 & 6 & 16.3 & 8.1 & 8 & 9.5 \\
\hline $7 / 8 / 2007$ & 5 & 7.4 & 9.4 & 7.1 & 6 & 12.8 \\
\hline Mean & $6.4^{b}$ & $3.83^{c}$ & $6.95^{\mathrm{a}}$ & $7.76^{\mathrm{a}}$ & $6.07^{b}$ & $5.74^{c}$ \\
\hline$\pm \mathrm{SE}$ & \pm 0.74 & \pm 0.59 & \pm 1.23 & \pm 1.06 & \pm 0.67 & \pm 0.86 \\
\hline F. value & \multicolumn{6}{|c|}{10.98} \\
\hline L. S. D & \multicolumn{6}{|c|}{1.11} \\
\hline
\end{tabular}

C. T. urticae: 


\section{1- Infestation rate of T. urticae motile stages during growing2006 season:}

Data presented in Table (5) showa peak of mean number of T. urticae motile stages $/ \mathrm{in}^{2}$ on the six tested cantaloupe cultivars during $11^{\text {th }}$ and $18^{\text {th }}$ of June then the population decrease during fortnight and then increase again during $9^{\text {th }}$ of July.

The statistical analysis of the present data clearly indicated that there were significant differences between the different six cantaloupe cultivars. Accordingly Duncan's multiple range test means indicated that Mirella and Ideal cultivars were the most susceptible ones. On the contrary, Vicar and E81-013 were moderately infested cultivars, while Magenta and E81-065 varieties considered the tolerant ones.

\section{2- Infestation rate of $T$. urticae motile stages during growing season of 2007:}

It is quite evident from the recorded results in Table (6) that the highest mean relative population densities of $T$. urticae motile stages on the different cantaloupe cultivars were concentrated in the period extended from $2^{\text {nd }}$ of June to $1^{\text {st }}$ of July.

Accordingly, Duncan's multiple range test between means clearly considered that Mirella and E81-013 were the most susceptible cultivars, on the other hand, Vicar was moderately infested cultivar. However, Ideal, Magenta and E81-065 cultivars considered the highly infested ones.

From the forcited results, one can conclude that the newly cultivars; E81-065 and Magenta were the lowest infested ones to most of the studied pests. So, it can be recommended in any Integrated Pest Management program. 
Table 5. Weekly mean number of $T$. urticae motile stages $/ \mathrm{in}^{2}$ of six cantaloupe $C$. melo cultivars at Qaha region, Qualyobia Governorate during summer plantation season of 2006.

\begin{tabular}{|c|c|c|c|c|c|c|}
\hline Cultivars & & an num & er of $T$. & ticae $\mathrm{m}$ & tile stages & $/ \mathrm{in}^{2}$ \\
\hline $\begin{array}{l}\text { Inspection } \\
\text { date }\end{array}$ & Ideal & $\begin{array}{l}\text { E81- } \\
065\end{array}$ & Mirella & Vicar & E81-013 & Magenta \\
\hline $30 / 4 / 2006$ & 2.9 & 2.4 & 3 & 2.8 & 2.7 & 2.5 \\
\hline $7 / 5 / 2006$ & 4.6 & 4.1 & 4.7 & 4.5 & 4.3 & 4.2 \\
\hline $14 / 5 / 2006$ & 4.3 & 3.5 & 4.6 & 4.1 & 4 & 3.8 \\
\hline $21 / 5 / 2006$ & 3.1 & 1.3 & 5.1 & 2 & 1.9 & 0.9 \\
\hline $28 / 5 / 2006$ & 3.9 & 3.2 & 4 & 3.8 & 3.7 & 3.5 \\
\hline $4 / 6 / 2006$ & 3.9 & 2.8 & 4.2 & 3.5 & 3.4 & 3.1 \\
\hline $11 / 6 / 2006$ & 6.9 & 5.1 & 7.1 & 6.5 & 6.6 & 5.8 \\
\hline $18 / 6 / 2006$ & 7.9 & 6.9 & 8.3 & 7.3 & 7.5 & 7.1 \\
\hline $25 / 6 / 2006$ & 3.9 & 2.7 & 4 & 3.1 & 3.2 & 2.9 \\
\hline 2/7/2006 & 5.1 & 4.1 & 5.3 & 4.9 & 4.8 & 4.5 \\
\hline $9 / 7 / 2006$ & 9.3 & 7.3 & 9.5 & 8.9 & 8.7 & 8.4 \\
\hline $16 / 7 / 2006$ & 3.7 & 2.8 & 4.2 & 3.2 & 3.1 & 2.9 \\
\hline $23 / 7 / 2006$ & 2 & 0.9 & 2.1 & 1.9 & 1.8 & 1.3 \\
\hline $31 / 7 / 2006$ & 0.2 & 0.1 & 0.3 & 0.1 & 0.1 & 0.1 \\
\hline $7 / 8 / 2006$ & 0.7 & 0.4 & 0.8 & 0.6 & 0.6 & 0.5 \\
\hline Mean & $4.16^{\mathrm{a}}$ & $3.17^{c}$ & $4.48^{\mathrm{a}}$ & $3.81^{\mathrm{b}}$ & $3.76^{b}$ & $3.43^{c}$ \\
\hline$\pm \mathrm{SE}$ & \pm 0.64 & \pm 0.55 & \pm 0.65 & \pm 0.62 & \pm 0.62 & \pm 0.61 \\
\hline F. value & & & & .16 & & \\
\hline L. S. D & & & & 31 & & \\
\hline
\end{tabular}

Studies on the susceptibility of watermelon cultivars against infestation by T. urticae were carried out by East and Edelson (1990). The present results are in agreement with the finding of McCreight (1992) on B. tabaci. 
Table 6. Weekly mean number of $T$. urticae motile stages $/ \mathrm{in}^{2}$ per leaf of six cantaloupe C. melo cultivars at Qaha region, Qualyobia Governorate during growing season of 2007 .

\begin{tabular}{|c|c|c|c|c|c|c|}
\hline \multirow{2}{*}{$\begin{array}{l}\text { Cultivars } \\
\text { Inspection } \\
\text { date }\end{array}$} & \multicolumn{6}{|c|}{ Mean number of $T$. urticae motile stages $/ \mathrm{in}^{2}$} \\
\hline & Ideal & $\begin{array}{c}\text { E81- } \\
065\end{array}$ & Mirella & Vicar & $\begin{array}{c}\text { E81- } \\
013\end{array}$ & Magenta \\
\hline $30 / 4 / 2007$ & 1 & 0.2 & 2.4 & 2.6 & 2.8 & 1.2 \\
\hline $7 / 5 / 2007$ & 2.4 & 3.2 & 3.4 & 5 & 4.6 & 3.4 \\
\hline $14 / 5 / 2007$ & 2.2 & 4.2 & 3.6 & 4.8 & 5.3 & 5.6 \\
\hline $21 / 5 / 2007$ & 3.6 & 7.6 & 4.6 & 4.4 & 7.8 & 3.2 \\
\hline $28 / 5 / 2007$ & 3.4 & 3.8 & 6.6 & 6.8 & 5.6 & 3.4 \\
\hline $4 / 6 / 2007$ & 5.3 & 5.4 & 8.2 & 9.4 & 9.8 & 5.2 \\
\hline $11 / 6 / 2007$ & 6.4 & 3.8 & 12.8 & 10.6 & 7 & 4.4 \\
\hline $18 / 6 / 2007$ & 8.4 & 8.4 & 15.6 & 10 & 10.4 & 8.2 \\
\hline $25 / 6 / 2007$ & 9.6 & 5.2 & 13.4 & 5.2 & 12 & 6.4 \\
\hline $2 / 7 / 2007$ & 10.8 & 3.2 & 6.8 & 7.4 & 10 & 4.4 \\
\hline $9 / 7 / 2007$ & 9.8 & 2.6 & 11.2 & 9 & 8.6 & 7.6 \\
\hline $16 / 7 / 2007$ & 2.6 & 2.4 & 11 & 6.2 & 6.2 & 5 \\
\hline $23 / 7 / 2007$ & 1.4 & 2.8 & 5.8 & 5.2 & 7 & 2.8 \\
\hline $31 / 7 / 2007$ & 0.6 & 0.4 & 3.2 & 2.4 & 1.4 & 1.8 \\
\hline $7 / 8 / 2007$ & 0.2 & 0.1 & 1.6 & 2 & 0.4 & 1.6 \\
\hline Mean & $4.51^{\mathrm{C}}$ & $3.55^{d}$ & $7.35^{\mathrm{a}}$ & $6.08^{b}$ & $6.59^{a}$ & $4.28^{\text {cd }}$ \\
\hline$\pm \mathrm{SE}$ & $\begin{array}{c} \pm \\
0.94\end{array}$ & \pm 0.63 & \pm 1.15 & $\begin{array}{c} \pm \\
0.72\end{array}$ & \pm 0.87 & \pm 0.77 \\
\hline F. value & \multicolumn{6}{|c|}{29.24} \\
\hline L. S. D & \multicolumn{6}{|c|}{0.77} \\
\hline
\end{tabular}

Moreno et al. (1993) screened the susceptibility of accessions comprising a range of cucurbit species and genera to infestation with $B$. tabaci and their findings indicated that all melon varieties and cucumber lines were severely infested by the pest, however, agrestis type melon $C$. melo var agrestis genotype Gatersleben $\mathrm{Cu}_{1}$ 90/ 1982 showing low susceptibility and this parameter varied in the tested wild species.

Ahmed (1994), studied the resistance and susceptibility of six cuccumber cultivars to Aphis gossypii, T. urticae and B. tabaci. Author's 
results indicated that the most resistant cultivar to the studied pests was Sweet Crunch FIII Sakata, and the most susceptible one especially to A. gossypii was Dominus- hy. However, these findings are in agreement with the data reported in the present study.

\section{II- Laboratory studies:}

Relation between certain phytochemical components and moisture content in leaves of different cantaloupe cultivars and population density of sap-sucking pests:

\section{A-T.tabaci :}

The lowest abundance of thrips occurred on leaves of E81-065 and Ideal cultivars (3.86 and 3.9 individuals / leaf) was associated with lower levels of protein (4.96 and 5.25\%), however, they were associated with higher levels of reducing sugars (1.64 and $1.73 \mathrm{mg} / \mathrm{gm}$ dry weight), non-reducing sugars( 3.7 and 3.64 $\mathrm{mg} / \mathrm{gm}$ dry wt.) and total sugars ( 5.34 and $5.4 \mathrm{mg} / \mathrm{gm}$ dry wt.). In addition, the lower percentage of phosphorous (0.24\%) was observed in the case of E81-065, on the other hand Mirella, E81-013 and Vicar cultivars showed higher total protein content in their leaves (5.26, 5.54 and 5.84\%, respectively) and harboured the highest infestation rates by $T$. tabaci (6.2, 6.96 and 5.16 individuals / leaf, respectively). Moreover, Mirella and Vicar cultivars contained the higher percentages of total carbohydrate in their leaves (3.28\%) and higher levels of phosphorous $(0.35 \%)$ and reducing sugars $(1.58 \mathrm{mg} / \mathrm{gm})$.However, Vicar showed intermediate levels of reducing sugars $(1.53 \mathrm{mg} / \mathrm{gm})$ and highest levels of non-reducing sugars ( $4.96 \mathrm{mg} / \mathrm{gm})$, total sugars $(6.2 \mathrm{mg} / \mathrm{gm})$ and phosphorous $(0.51 \%)$, in addition, Vicar contained higher percentage of moisture content (89.51\%). The moderate infestation rate of thrips which was recorded on leaves of Magenta variety (4.99 individuals / leaf) being associated with an intermediate levels of non- reducing, total sugars, potassium and moisture content $(2.2,3.63$ and $15.99 \mathrm{mg} / \mathrm{gm}$ and $85.74 \%$, respectively) 
Table 7. Relation between certain phytochemical components of leaves dry weight of six cantaloupe cultivars during three vegetative growth stages and mean infestation rates with $T$. tabaci in 2007 season.

\begin{tabular}{|c|c|c|c|c|c|c|c|c|c|}
\hline \multirow{4}{*}{ Cultivars } & \multirow{4}{*}{$\begin{array}{l}\text { Pest } \\
\text { count }\end{array}$} & \multicolumn{7}{|c|}{ Phytochemical components } & \multirow{4}{*}{$\begin{array}{c}\text { Moisture } \\
\text { content } \\
(\%)\end{array}$} \\
\hline & & \multicolumn{4}{|c|}{$\mathrm{Mg} / \mathrm{gm}$} & \multicolumn{3}{|c|}{$(\%)$} & \\
\hline & & \multicolumn{3}{|c|}{ Sugar } & \multirow[b]{2}{*}{ Potassium } & \multirow[b]{2}{*}{$\begin{array}{c}\text { Total } \\
\text { protein }\end{array}$} & \multirow[b]{2}{*}{$\begin{array}{l}\text { Carboh- } \\
\text { ydrate }\end{array}$} & \multirow[b]{2}{*}{$\begin{array}{c}\text { Phosph- } \\
\text { orous }\end{array}$} & \\
\hline & & Reduced & $\begin{array}{c}\text { Non- } \\
\text { reduced }\end{array}$ & Total & & & & & \\
\hline Ideal & $3.9^{c}$ & $1.73^{\mathrm{a}}$ & $3.64^{\mathrm{a}}$ & $5.4^{\mathrm{a}}$ & $16.59^{\mathrm{bc}}$ & $5.25^{\mathrm{bc}}$ & 5.34 & $0.32^{\mathrm{ab}}$ & $87.53^{a}$ \\
\hline E81-065 & $3.86^{c}$ & $1.64^{\mathrm{ab}}$ & $3.7^{\mathrm{a}}$ & $5.34^{\mathrm{a}}$ & $15.67^{c}$ & $4.96^{c}$ & 5.31 & $0.24^{b}$ & $89.96^{a}$ \\
\hline Mirella & $6.2^{\mathrm{ab}}$ & $1.46^{\mathrm{c}}$ & $3.5^{\mathrm{ab}}$ & $4.96^{\mathrm{ab}}$ & $18.52^{a}$ & $5.26^{\mathrm{bc}}$ & 4.96 & $017^{b}$ & $77.81^{b}$ \\
\hline Vicar & $5.16^{\mathrm{bc}}$ & $1.53^{\mathrm{bc}}$ & $4.69^{a}$ & $6.2^{\mathrm{a}}$ & $16.93^{\mathrm{ab}}$ & $5.84^{\mathrm{a}}$ & 6.21 & $0.51^{a}$ & $89.51^{a}$ \\
\hline E81-013 & $6.96^{\mathrm{a}}$ & $1.58^{\mathrm{bc}}$ & $1.7^{\mathrm{c}}$ & $3.28^{\mathrm{c}}$ & $16.25^{\mathrm{bc}}$ & $5.54^{\mathrm{ab}}$ & 3.28 & $0.35^{\mathrm{ab}}$ & $87.29^{a}$ \\
\hline Magenta & $4.99^{b c}$ & $1.48^{\mathrm{C}}$ & $2.2^{\mathrm{bc}}$ & $3.63^{b c}$ & $15.99^{\mathrm{bc}}$ & $5.54^{\mathrm{ab}}$ & 3.65 & $0.26^{b}$ & $85.74^{a}$ \\
\hline F value & 5.52 & 5.06 & 4.8 & 4.52 & 5.34 & 3.84 & 0.17 & 2.96 & 5.37 \\
\hline L. S. D. & 1.65 & 0.13 & 1.43 & 1.5 & 1.25 & 0.44 & - & 0.2 & 5.46 \\
\hline Corr. (r) & & -0.46 & 0.05 & 0.01 & 0.36 & $0.51^{*}$ & 0.01 & -0.06 & 0.05 \\
\hline
\end{tabular}

Means followed by the same letters within the same column are not significantly different at $5 \%$ level of probability according to Duncan's multiple range test.

L.S.D. =Least significant difference .

* Significant $(p<0.05)$. 


\section{B-B, tabaci nymphs :}

The lowest mean population density of B. tabaci nymphs occurred on E81-065 cultivar (3.35 nymphs/ in ${ }^{2}$ of leaf ) were associated with lowest levels of phosphorous and total protein ( 0.24 and $4.96 \%$ ),however, E81-065 cultivar contained higher levels of reducing, non-reducing and total sugars, carbohydrate and moisture content (1.64, 3.7 and $5.34 \mathrm{mg} / \mathrm{gm}, 5.31$ and 89.96\%).On the contrary, the cultivars which showed higher total carbohydrates in their leaves were Mirella, Ideal and Vicar ( 4.96, 5.34 and $6.21 \%$, respectively) harboured higher rates by B.tabaci nymphs $(6.11,6.81$ and 6.75 nymphs / in $^{2}$, respectively). In addition, Ideal which harboured the highest infestation rates by $B$. tabaci nymphs contained higher levels of reducing, nonreducing and total sugars $(1.73,3.64$ and $5.4 \mathrm{mg} / \mathrm{gm}$, respectively). However, Ideal cultivar contained lower percentage of total protein and moisture content $(4.69,6.2$ $\mathrm{mg} / \mathrm{mg}, 0.51,5.84$ and $89.51 \%$, respectively), however, intermediate levels of reducing sugars were recorded in leaves of Vicar cultivar $(1.53 \mathrm{mg} / \mathrm{gm})$. It could be also noticed that E81-013 variety which harboured higher infestation rates by B.tabaci nymphs (6.21 nymphs $\left./ \mathrm{in}^{2}\right)$ contained higher percentage $\mathrm{s}$ of phosphorous and total protein in their leaves ( 0.35 and $5.54 \%$, respectively), on the other hand, E81-013 cultivar contained intermediate levels of reducing sugars, potassium and moisture levels $(1.58,16.25 \mathrm{mg} / \mathrm{gm}$ and $87.29 \%$, respectively) and lower levels of nonreducing and total sugars as well as carbohydrate content $(1.7$ and $3.28 \mathrm{mg} / \mathrm{gm}$, and $3.28 \%$, respectively). Magenta which harboured intermediate infestation rates with $B$. tabaci nymphs (5.07 nymphs/ in $^{2}$ ) was associated with intermediate levels of nonreducing and total sugars, potassium, phosphorous and moisture content ( $2.20,3.63$ and $15.99 \mathrm{mg} / \mathrm{gm}, 0.26$ and $58.74 \%$, respectively).

\section{T. urticae :}

As shown in Table (9), it is clear that the highest mean abundance of T. urticae motile stages (7.78 individuals / $\mathrm{in}^{2}$ ) occurred on leaves of Mirella variety which contained higher levels of non-reducing sugar ( $3.5 \mathrm{mg} / \mathrm{gm}$ dry wt.) and carbohydrate (4.96\%) followed by Vicar and

E81-013cultivars (6.65 and 6.77 individuals / $\mathrm{in}^{2}$ ) which contained higher percentages of protein (5.84 and 5.54\%) and moisture content (89.51 and $87.29 \%$ ). In addition, Vicar contained the higher levels of non-reducing and total sugars, protein, carbohydrate, phosphorous and moisture content $(4.69,6.2,5.84 \mathrm{mg} / \mathrm{gm}, 6.21,0.51$ and 89.51). While, the intermediate mean abundance of $T$. urticae motile stages which was recorded on leaves of Magenta and Ideal cultivars(4.45 and 4.58 individuals $/ \mathrm{in}^{2}$ ) was associated with intermediate levels of phosphorous ( 0.26 and $0.32 \%$, respectively). Moreover, Ideal contains low levels of total protein in their leaves $(5.25 \%)$. The lowest mean abundance of $T$. urticae motile stages were recorded on leaves of E81-065 cultivar (4.12 individuals / $\mathrm{in}^{2}$ ) which was associated with low levels of protein and phosphorous (4.96 and $0.24 \%$, respectively) .

Ibrahim et al . (2008), analyzed the chemical components in cucurbits and the obtained results indicated that the population of $T$. urticae positively correlated with an increasing in nutrient contents of leaves such as crude proteins, crude fats and carbohydrates. 
Table 8. Correlation between certain phytochemical components of leaves dry weight of six cantaloupe cultivars of $B$. tabaci nymphs during 2007 season.

\begin{tabular}{|c|c|c|c|c|c|c|c|c|c|}
\hline \multirow{4}{*}{ Cultivars } & \multirow{4}{*}{$\begin{array}{l}\text { Pest } \\
\text { count }\end{array}$} & \multicolumn{7}{|c|}{ Phytochemical components } & \multirow{4}{*}{$\begin{array}{c}\text { Moisture } \\
\text { content } \\
\text { (\%) }\end{array}$} \\
\hline & & \multicolumn{4}{|c|}{$\mathrm{Mg} / \mathrm{gm}$} & \multicolumn{3}{|c|}{$(\%)$} & \\
\hline & & \multicolumn{3}{|c|}{ Sugar } & \multirow[b]{2}{*}{ Potassium } & \multirow{2}{*}{$\begin{array}{c}\text { Total } \\
\text { protein }\end{array}$} & \multirow{2}{*}{$\begin{array}{l}\text { Carboh- } \\
\text { ydrate }\end{array}$} & \multirow{2}{*}{$\begin{array}{c}\text { Phosph- } \\
\text { orous }\end{array}$} & \\
\hline & & Reduced & $\begin{array}{c}\text { Non- } \\
\text { reduced }\end{array}$ & Total & & & & & \\
\hline Ideal & $6.81^{a}$ & $1.73^{\mathrm{a}}$ & $3.64^{a}$ & $5.4^{\mathrm{a}}$ & $16.59^{b c}$ & $5.25^{\mathrm{bc}}$ & 5.34 & $0.32^{\mathrm{ab}}$ & $87.53^{a}$ \\
\hline E81-065 & $3.35^{\mathrm{b}}$ & $1.64^{\mathrm{ab}}$ & $3.7^{\mathrm{a}}$ & $5.34^{\mathrm{a}}$ & $15.67^{c}$ & $4.96^{c}$ & 5.31 & $0.24^{b}$ & $89.96^{\mathrm{a}}$ \\
\hline Mirella & $6.11^{a b}$ & $1.46^{\mathrm{c}}$ & $3.5^{\mathrm{ab}}$ & $4.96^{\mathrm{ab}}$ & $18.52^{a}$ & $5.26^{\mathrm{bc}}$ & 4.96 & $017^{\mathrm{b}}$ & $77.81^{b}$ \\
\hline Vicar & $6.75^{\mathrm{a}}$ & $1.53^{\mathrm{bc}}$ & $4.69^{a}$ & $6.2^{\mathrm{a}}$ & $16.93^{\mathrm{ab}}$ & $5.84^{a}$ & 6.21 & $0.51^{a}$ & $89.51^{a}$ \\
\hline E81-013 & $6.21^{a}$ & $1.58^{\mathrm{bc}}$ & $1.7^{\mathrm{c}}$ & $3.28^{c}$ & $16.25^{\mathrm{bc}}$ & $5.54^{\mathrm{ab}}$ & 3.28 & $0.35^{\mathrm{ab}}$ & $87.29^{a}$ \\
\hline Magenta & $5.07^{\mathrm{ab}}$ & $1.48^{\mathrm{C}}$ & $2.2^{\mathrm{bc}}$ & $3.63^{b c}$ & $15.99^{b c}$ & $5.54^{\mathrm{ab}}$ & 3.65 & $0.26^{\mathrm{b}}$ & $85.74^{a}$ \\
\hline F value & 2.15 & 5.06 & 4.8 & 4.52 & 5.34 & 3.84 & 0.17 & 2.96 & 5.37 \\
\hline L. S. D. & 2.82 & 0.13 & 1.43 & 1.5 & 1.25 & 0.44 & - & 0.2 & 5.46 \\
\hline Corr. (r) & & 0.15 & 0.16 & 0.14 & -0.24 & -0.07 & 0.17 & 0.27 & -0.32 \\
\hline
\end{tabular}

Means followed by the same letters within the same column are not significantly different at $5 \%$ level of probability according to Duncan's multiple range test.

L.S.D. =Least significant difference. 
Table 9. Phytochemical analysis of leaves dry weight of six cantaloupe Cultivars during different three growth stages in relation to mean infestation rates with $T$. urticae motile stages throughout 2007 season .

\begin{tabular}{|c|c|c|c|c|c|c|c|c|c|}
\hline \multirow{4}{*}{ Cultivars } & \multirow{4}{*}{$\begin{array}{l}\text { Pest } \\
\text { count }\end{array}$} & \multicolumn{7}{|c|}{ Phytochemical components } & \multirow{4}{*}{$\begin{array}{c}\text { Moisture } \\
\text { content } \\
(\%)\end{array}$} \\
\hline & & \multicolumn{4}{|c|}{$\mathrm{Mg} / \mathrm{gm}$} & \multicolumn{3}{|c|}{$(\%)$} & \\
\hline & & \multicolumn{3}{|c|}{ Sugar } & \multirow[b]{2}{*}{ Potassium } & \multirow{2}{*}{$\begin{array}{c}\text { Total } \\
\text { protein }\end{array}$} & \multirow{2}{*}{$\begin{array}{l}\text { Carboh- } \\
\text { ydrate }\end{array}$} & \multirow{2}{*}{$\begin{array}{c}\text { Phosph- } \\
\text { orous }\end{array}$} & \\
\hline & & Reduced & $\begin{array}{l}\text { Non- } \\
\text { reduced }\end{array}$ & Total & & & & & \\
\hline Ideal & $4.58^{b c}$ & $1.73^{\mathrm{a}}$ & $3.64^{a}$ & $5.4^{\mathrm{a}}$ & $16.59^{b c}$ & $5.25^{\mathrm{bc}}$ & 5.34 & $0.32^{\mathrm{ab}}$ & $87.53^{a}$ \\
\hline E81-065 & $4.12^{c}$ & $1.64^{\mathrm{ab}}$ & $3.7^{\mathrm{a}}$ & $5.34^{\mathrm{a}}$ & $15.67^{c}$ & $4.96^{c}$ & 5.31 & $0.24^{b}$ & $89.96^{\mathrm{a}}$ \\
\hline Mirella & $7.78^{\mathrm{a}}$ & $1.46^{\mathrm{c}}$ & $3.5^{\mathrm{ab}}$ & $4.96^{\mathrm{ab}}$ & $18.52^{\mathrm{a}}$ & $5.26^{\mathrm{bc}}$ & 4.96 & $017^{\mathrm{b}}$ & $77.81^{\mathrm{b}}$ \\
\hline Vicar & $6.65^{a b}$ & $1.53^{\mathrm{bc}}$ & $4.69^{a}$ & $6.2^{\mathrm{a}}$ & $16.93^{\mathrm{ab}}$ & $5.84^{a}$ & 6.21 & $0.51^{a}$ & $89.51^{a}$ \\
\hline E81-013 & $6.77^{\mathrm{ab}}$ & $1.58^{\mathrm{bc}}$ & $1.7^{c}$ & $3.28^{c}$ & $16.25^{\mathrm{bc}}$ & $5.54^{\mathrm{ab}}$ & 3.28 & $0.35^{\mathrm{ab}}$ & $87.29^{a}$ \\
\hline Magenta & $4.45^{\mathrm{bc}}$ & $1.48^{\mathrm{C}}$ & $2.2^{\mathrm{bc}}$ & $3.63^{b c}$ & $15.99^{b c}$ & $5.54^{\mathrm{ab}}$ & 3.65 & $0.26^{\mathrm{b}}$ & $85.74^{\mathrm{a}}$ \\
\hline F value & 4.4 & 5.06 & 4.8 & 4.52 & 5.34 & 3.84 & 0.17 & 2.96 & 5.37 \\
\hline L. S. D. & 2.3 & 0.13 & 1.43 & 1.5 & 1.25 & 0.44 & - & 0.2 & 5.46 \\
\hline Corr. (r) & & -0.2 & 0.15 & 0.13 & 0.28 & 0.19 & 0.13 & 0.13 & -0.17 \\
\hline
\end{tabular}

Means followed by the same letters within the same column are not significantly different at $5 \%$ level of probability according to Duncan's multiple range test.

L.S.D. =Least significant difference. 


\section{REFERENCES}

1. Ahamed, M.A. 1994 . Differences in susceptibility of six cucumber cultivars to infestation by Aphis gossypii Glov., Tetranychus urticae and Bemisia tabaci as correlated to protein and amino acid contents. Ann. Agric. Sci. Moshtohor, 32 (4) : $2189-2194$.

2. Duffus 1987.Whitefly transmission of plant viruses. In Carrent Topics in Vector Research, (4) 73 - 91.

3. East, D. A. and J.V. Edelson. 1990. Evaluation of watermelon cultivars for resistance to spider mites. Res. Rep. Agric. Exp. Station Div. Agric. Oklahoma State Univ., P-914, 4 pp.

4. Forsee, W.T. 1938. Detremination of sugar in plant marerial a photocolormetric method .Inds. Eng. Chem. Annal. 10th ed : 411- 418.

5. McCreight, J. D. 1992 . Preliminary screening of melons for sweet potato of melons for sweetpotato whitefly resistance. Report. Cucurbit. Genetics. Cooperative, (15) : 59-61.

6. Michel, K. A., J.K. Gilles , P. A. Hamilton and F. Smith 1956. Clorometric method for determination of sugars and related substances. Analytical Chemistry, 28 (3) : 302 - 307.

7. Morales, P.A. and Y. R. Bastidas. 1997. Evaluation of the resistance of eight cultivars of melon Cucumis melo L. to attack by the whitefly Bemisia tabaci (Gennadius) (Homoptera : Aleyrodidae) in the Los Perozos area, Estado Falcon, Venezuela, Boletin- de-Entomologia

-Venezolana, 12 (2) : 141 -149.

8. Moreno, V., J. L.Gomez-Aguilera, C. Guerau-de Arellano and L. A. Roig. 1993. Preliminary screening of cucurbits species for Bemisia tabaci Genn. whitefly resistance.Report.Cucurbit Genetics Cooperative, (16) : 87-89.

9. Osman, A . A. ,G.I. Zohdi and S. Abo - Kora. 1985. The role of Egyptian Clover in dispersing Tetranychid mites to cotton. Proceeding of Egypt's national conference of Entomology,1 : 141- 148.

10. Pregl, F. 1945 .Quantitative oraginc microanalysis. 4 th ed. J. and A.Chundril 4td. London : $94: 101$.

11. Troug, E. and A. H. Meyer. 1939. Improvement in deiness calorimetric for phosphorous and arsenic. Ind .Eng .Chem . Annal - Ed., 1: 136- 139.

12. Watt, B.K. and A.L.Merrill.,1963. Composition of foods. U.S. Dept.of Agr.,Agr.Hand book No 1.8.190p 


\section{حساسية بعض هجن من الكنتالوب للإصابة بثلاث آفات

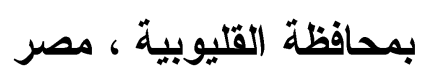

\section{سامية أحمد جلال متولى ، ،إبراهيم فتحى إبر اهيم شكرى'، محمد وجدى فريد يونس 3 يمنى نبيل محد عبدالله 1}

$$
\begin{aligned}
& \text { 1. معهُ بحوث وقاية النباتات- مركز البحوث الزراعبة، الدقى ، الجبزة . } \\
& \text { 2. } \\
& \text { 3. قسم علم الحيوان- كلية العلوم- جامعة المنوفية- مصر. }
\end{aligned}
$$

تم إجر اء دراسات حقلية ومعملية تهدف إلى دراسة حساسية ستة هن من الكنتالوب وهى للإصابة بتربس (Magenta , E81-013 , Vicar ، Mirella ، E81-065 ، Ideal ) القطن و البصل و ذبابة القطن و الطماطم البيضاءو الأكاروس العنكبوت ذو البقعتين وذلك خلا لهل العروة الصيفية. التجارب الحقلية نم إجر ائها خلال موسمين متعاقبين من الزراعة ( 2006 و 2007). ووجدت

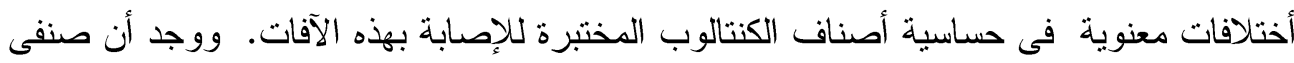

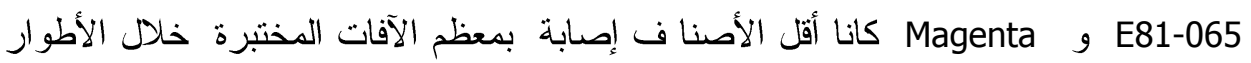

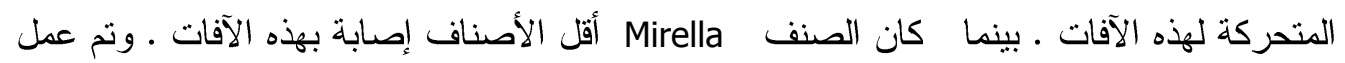
تحليل كيميائى للأور اق الجافة من الأصناف الست المختبرة لمعرفة أسباب الأختلاف فى حساسية

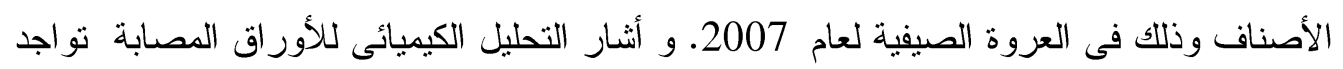

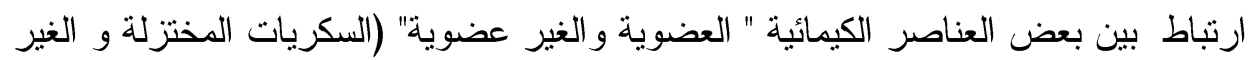

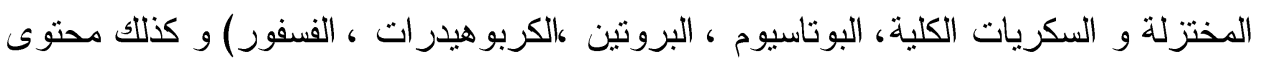
الرطوبة و كثافة عشائر تربس القطن و البصل و ذبابة القطن و الطماطم البيضاء و الأكاروس ليرونس العنكبوتى ذو البقعتين. 